\title{
STUDIES ON THE ENZYMATIC DEGRADATION OF COCARBOXYLASE
}

\author{
SHIGEO HORIE \\ Department of Biochemistry, Faculty of Medicine, \\ University of Tokyo, Hongo, Tokyo
}

(Received August 27, 1957)

It can hardly be said that sufficient knowledge has been accumulated in the literature concerning the enzymatic degradation of cocarboxylase. Lohmann and Schuster (1) studied the nature of the phosphoric acid of cocarboxylase (thiamine diphosphate, TDP), and found that 50 per cent of the total phosphoric acid was hydrolysed in $1 N$ hydrochloric acid at $100^{\circ}$ within 15 minutes, whereas the remaining 50 per cent was much more resistant to the hydrolysis for liberating inorganic phosphate (iP) by heating for 90 minutes. Using the dialysate of kidney extract, they examined the action of so-called alkaline phosphatase on TDP, and stated that the easily hydrolysable phosphoric acid was liberated very quickly, whereas the hardly hydrolysable one much slower. Partially purified acid phosphatase from prostate was also used. By this enzyme, however, both kinds of the phosphoric acid were liberated at the same rate.

It has been known for many years that alkaline-washed dry bakers' yeast (etiozymase) produces carbon dioxide from pyruvate in the presence of TDP and the action is greatly stimulated by thiamine (2). As to this phenomen Westenbrink et al. (3) presumed that the phosphoric acid molecules were liberated one by one by the action of a single enzyme of bakers' yeast, and thiamine inhibits the activity of this enzyme.

The author (4) studied more directly the preventive effect of thiamine on the inactivation of TDP by etiozymase. Recently, using the partially purified apocarboxylase preparations, Aoshima (5) showed the inhibitory action of thiamine on the liberation of iP from TDP.

As to whether a specific thiamine-pyrophosphatase is present or not, Naidoo and Pratt (6) presumed the presence of a specific enzyme differing from other phosphatases in the brains of the rat, etc., mainly from the results of histochemical studies.

On the other hand, Kornberg and Pricer (7) described that there was a strong TDP-decomposing activity (TDPase activity) in the crude extract of potatoes, and most of this activity disappeared during the course of the purification of nucleotide pyrophosphatase. They pointed out, however, even the most purified enzyme preparation had some TDP-decomposing activity, though far weaker than the activity for DPN.

Plaut (8) purified an enzyme specific for inosine diphosphate from the acetone 
powder of bovine liver mitochondria. It is not known whether this enzyme can act upon TDP or not.

Miura, Fujiwara, et al. (9) made a comparative study for TDP-decomposing activity using various tissue homogenates of rats.

The author ${ }^{1}$ has studied the nature of TDPase activities of the homogenates of rat brain, dog kidney, and bovine kidney, and also examined the enzymolo gical properties of the preparations obtained from extracts of dog kidney, bovine kidney, and dry yeast. In this paper, the results of the studies are reported.

\section{Experimental}

\section{Choice of Methods for Estimating the Degradation of TDP.}

For estimating the amount of TPD decomposed, three methods can be used. i.e., (a) manometric determination of the decrease in TDP using etiozymase or apocarboxylase, $(b)$ colorimetric determination of inorganic phosphate liberated, and $(c)$ fluorometric determination of thiamine liberated. With each of these methods, a side-view of the decomposition of TDP can be obtained. However, quantitative aspects of all the possible reaction products cannot be clarified with a single method alone. In the present studies iP determinations were mainly used, and when necessary, the manometric estimation of TDP using apocarboxylase was also used. In addition, the detection of TDP, thiamine monophosphate (TMP), and thiamine was applied using paper electrophoresis.

For determining iP, Gomori's original method (10) was adopted. By this method, iP liberation from TDP in the course of assay procedure was not observed.

\section{Influence of Thiamine for the Determination of iP.}

Thiamine reacts with phosphomolybdic acid to form an insoluble complex. Thus, when thiamine exists in the reation mixtures together with iP, the colored solutions become turbid. The influence of this turbidity upon the determination was not so large provided that the colored solution was diluted, and, in addition, that the concentrations of thiaimine and iP in the samples were restricted in a settled range. In the early stnges of this study, iP was determined under this condition. Later, however, Uehara's method (11), in which the turbidity was counteracted by carrying out the photometric measurements in the half-saturated ammonium chloride solution, was applied to Gomori's method, and good results were obtained. The outlines of the latter method are as follows.

To a $25 \mathrm{ml}$-graduated test tube, less than $10 \mathrm{ml}$ of the sample (iP not exceeding $100 \gamma$, thiamine not exceeding $200 \mathrm{r}), 2.5 \mathrm{ml}$ of Gomori's acid-molybdate reagent, and $10 \mathrm{ml}$ of saturated ammonium chloride solution are added in this order, and mixed well. Then, $1 \mathrm{ml}$ of 1 per cent monomethyl $p$-aminophenol sulfate in 3 per cent $\mathrm{NaHSO}_{3}$ is added and made up to $25 \mathrm{ml}$ with distilled water. After mixing. well the solution, the test tube is kept at $25^{\circ}$ for 45 minutes in a water bath. Photometric reading is made in 45 to 90 minutes $(a$ $=25 \mathrm{~mm}$, red filter). A blank test is to run parallel using water in place of sample solutions. The turbidity due to thiamine always disappeared during the incubation period. Under these conditions, $200 \gamma$ of thiamine did not show any influence on the determination of iP, and the added ammonium chloride gave scarcely any decrease in the extinction.

1 Procedings have been reported at several meetings $(22,23)$ 
3. An Example for the Simultaneous Determination of the iP Liberated and the Decrease in TDP Activity.

The TDP-decomposing enzyme used in this experiment was prepared from bovine kidney autolysate by acetone fractionation, trypsin treatment, and ammonium sulfate fractionation. Cocarboxylase activity was determined manometrically using apocarboxylase prepared from yeast according to the method of Yamamura et al. (12). As is illustrated in Fig. 1, the decrease of TDP and the liberation of iP coincided well.

\section{Conditions for Estimating} the Activity of TDP-decomposing

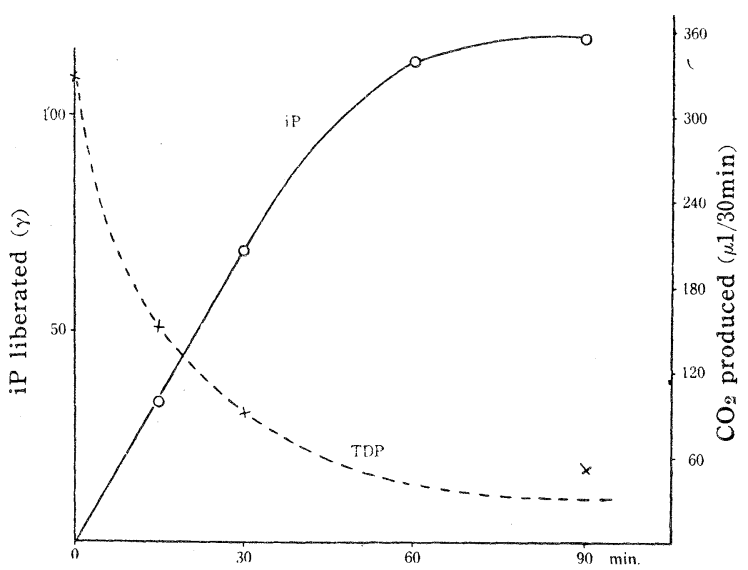

FIG. 1 Degradation of TDP and Liberation of Inorganic Phosphate. Enzyme.

The activity of phosphatases is often greatly influenced by the composition of buffer solutions used (13). In the present study, Michaelis' veronal-acetate$\mathrm{HCl}$ buffer ( $\mathrm{pH} 4-9$ ) was used because of its broad buffering range and relative constancy of the composition over a wide range of $\mathrm{pH}$. The basic composition of reaction mixture, expressed in $\mathrm{ml}$, was as follows. If needed, each component and the total fluid volume were multiplied.

Buffer solution, $1.0 ; 1$ per cent magnesium sulfate, $0.2 ; M / 250$. substrate, 0.4 ; enzyme solution plus water, 0.4 ; total volume, 2.0 .

The activity of the enzyme preparation was assayed under the conditions where the substrate decompoition was kept less than 30 per cent, and the amount of the enzyme was varied. Incubation was carried out at $38^{\circ}$ for $10-15$ minutes. When the fluid containing insoluble particulate materials, e.g., homogenate, were used as enzyme, the incubation was carried out with continuous shaking. The reaction was stopped by adding equal volumes of 10 per cent trichloroacetic acid, followed by the filtration of the precipitate formed. Liberated iP was determined with $2 \mathrm{ml}$ of the filtrate. Control experiments ran parallel with all the samples, and the blank values (reaction time 0 minute) was subtracted from each main value to correct the small amount of iP contained in the reagents and enzyme preparations.

\section{Miscellaneous.}

The protein concentration in the enzyme solutions was determined with micro-Kjeldahl method as modified by Parnas. The protein concentration in the fractions obtained by column chromatography and zone electrophoresis was estimated with Folin's phenol reagent (14) as modified by Lowry et al. (15). For the estimation of inorganic pyrophosphate (iPP), Kornberg's method (16) was applied.

TDP was kindly supplied from Dr. Matsukawa of the Takeda Research 
Laboratory. The purity of the samples was estimated to be 90 per cent by both electrophoretic and enzymatic analysis. They contained small amount of TMP and iP but no thiamine. TMP also supplied from Dr. Matsukawa, contained neither TDP nor thiamine as tested by electrophoresis.

\section{RESULTS AND DISCUSSION}

\section{TDP-Decomposing Activity of Rat Brain Homogenate}

\section{1. $p H$-Activity Curve}

Figs. 2-4 illustrate the $\mathrm{pH}$-activity curve obtained from an experiment using 10 per cent rat brain homogenate (in 1 per cent $\mathrm{KCl}$ ).

When TDP was used as substrate, the homogenate showed an accessory activity peak at $\mathrm{pH} 6$ to 7 which may correspond to TDPase found by Naidoo and Pratt in histochemical studies. Under the author's experimental conditions, however, a much higher decomposing activity was observed in the more alkaline region (adjacent to $\mathrm{pH}$ ). But the relative activity at $\mathrm{pH} 6$ to 7 varied

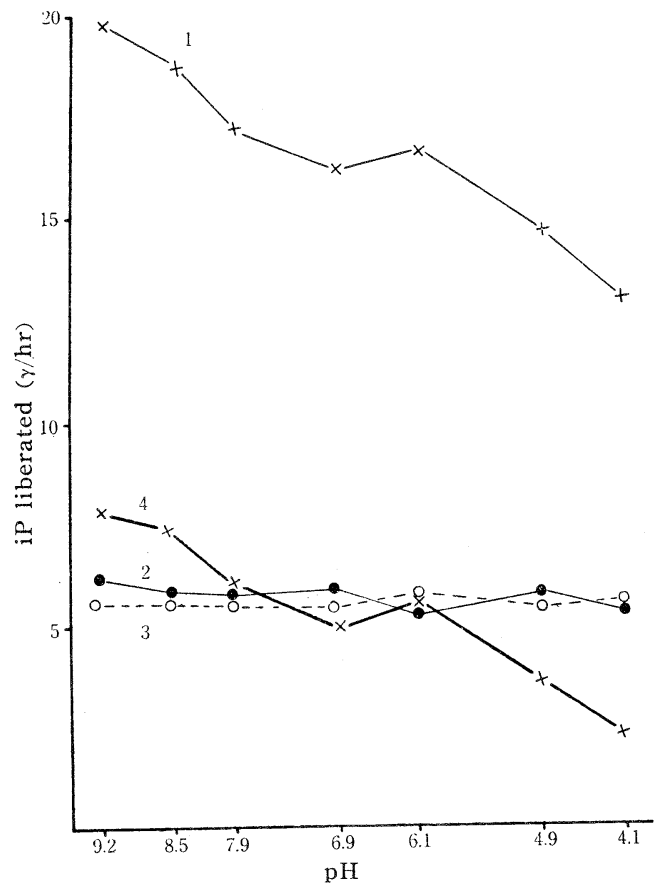

Fig. 2 Degradation of TDP by Rat Brain Homogenate.

1. Total iP liberated.

2. iP liberated from endogenous substrate.

3. iP liberated from TDP by spontaneous decomposition plus iP contained in TDP sample.

4. iP liberated from TDP by enzyme reaction.

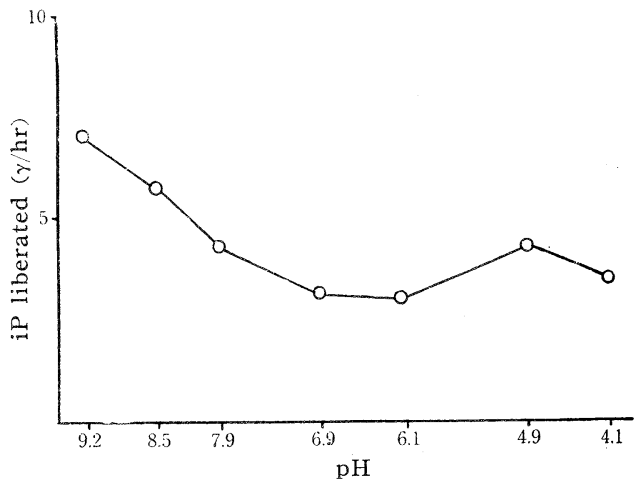

FIG. 3 Degradation of GP by Rot Brain Homogenate.

from rat to rat and, in some rare cases, it was even higher than that of $\mathrm{pH}$ 9.2 in agreement with the findings of Naidoo and Pratt in chicken brains. The decomposing activity for $\beta$-glycerophosphate (GP) showed typical peaks of acid and alkaline phosphatases (Fig. 3). On the contrary, $\mathrm{pH}$-activity curve for TMP was similar to that of TDP (Fig. 4).

\section{Influence of Osmotic Factor}

It is well known that the mitochondrial adenosine triphosphate-decomposing activity (ATPase activity) 
depends upon the osmotic factor, exhibiting the lowest activity in isotonic media (17). TDPase activity at $\mathrm{pH} 6.9$ was examined in this respect, and it was found that, though less significant than in the case of ATPase, it clearly depends upon the osmotic pressure and exhibits the lowest activity in isotonic media. From this result, at least some part of TDPase activity is assumed to be bound with cellular structures.

\section{Influence of Fluoride}

Influence of fluoride was exami-

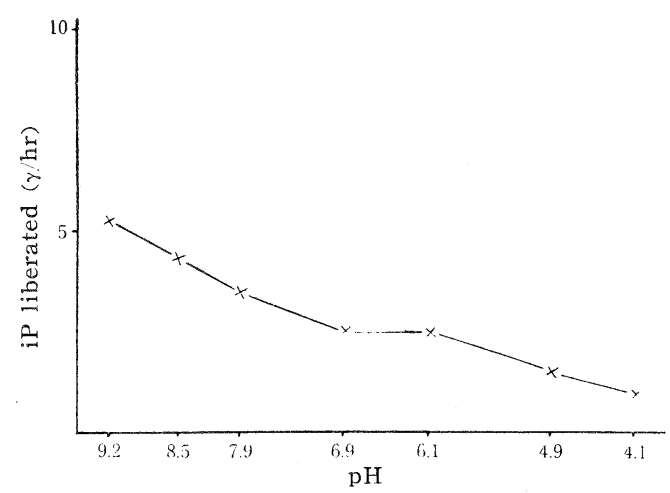

FIt. 4. Degradation of TMP by Rat Brain Homogenate. ned with 10 per cent rat brain homogenate (Table I). At the concentrtion of $M / 25$, inhibition by fluoride was

TABLE I

Effect of Fluoride on the Activity of TDPase and GPase of Rat Brain Homogenate.

\begin{tabular}{c|c|cc}
\hline & & \multicolumn{2}{|c|}{ iP liberated in $\gamma / h r$} \\
& $\mathrm{pH}$ & Without NaF & With NaF $^{a}$ \\
\hline TDPase & 9.2 & 7.10 & 4.65 \\
& 6.9 & 4.85 & 4.10 \\
GPase & 9.2 & 6.35 & 1.85 \\
\hline
\end{tabular}

a Final concentration, $M / 25$.

insignificant against the decomposition of TDP compared with against that of GP, especially at pH 6.9. Decomposition of GP was strongly inhibited by fluoride at $\mathrm{pH}$ 9.2. These findings coincide well with the histochemical evidence of Naidoo and Pratt (6).

\section{Fractionation of TDPase in Rat Brains by Differential Centrifuging, and Trials for Extracting the Particle-bound Activity}

\section{Fractionation by Differential Centrifuging}

Since at least some part of the TDPase activity was assumed to be bound with structural proteins, the possibility of physiological presence of a soluble enzyme and of extracting the bound enzyme into solution was tested. For the first step, the differential centrifuging was carried out. As the cell composition of the brain is different from that of the liver, etc., and is hardly fractionated in an ordinary way, the activity was determined with fractions obtained by various centrifugal forces. The results are illustrated in Table II. It is apparent that a considerable part of the enzyme activity decomposing TDP at $\mathrm{pH} 6.9$ is bound to cell structure. However, the possibility of physiological existence of some part of the activity in the soluble fraction is not to be excluded. 
TABLE II

TDPase Activity of Rat Brain Homogenate Fractions Obtained by Centrifuging ( $\mathrm{pH} 6.9$ )

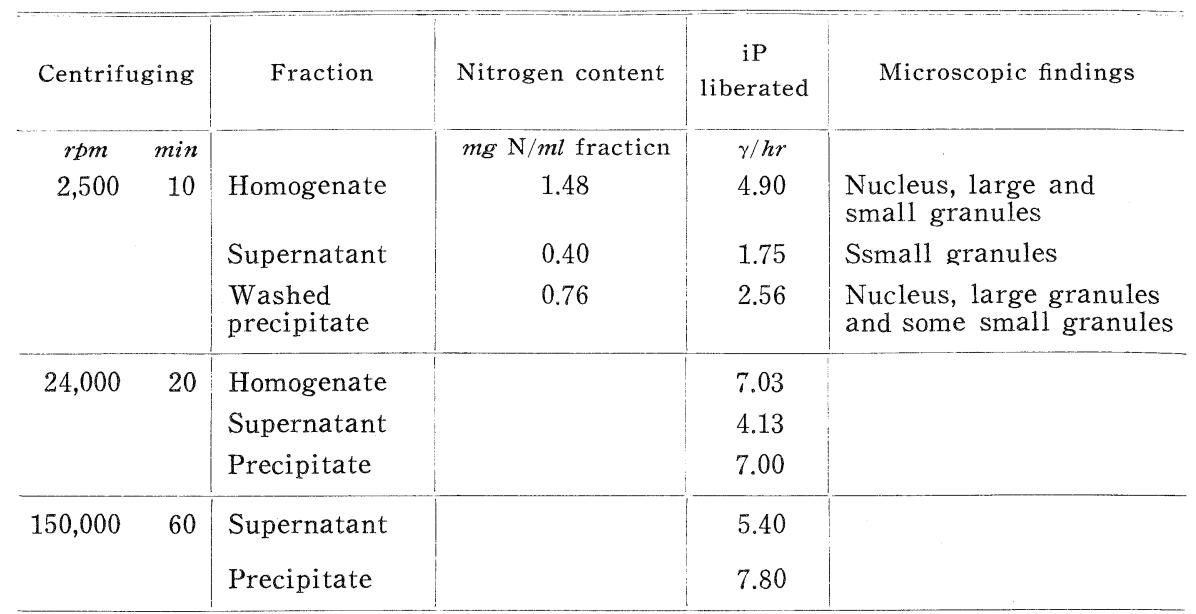

\section{Trials for Extracting the Bound Enzyme}

Trials for extracting the enzyme activity bound to insoluble part, and thus for increasing the yield of soluble enzyme were carried out. Freezing and

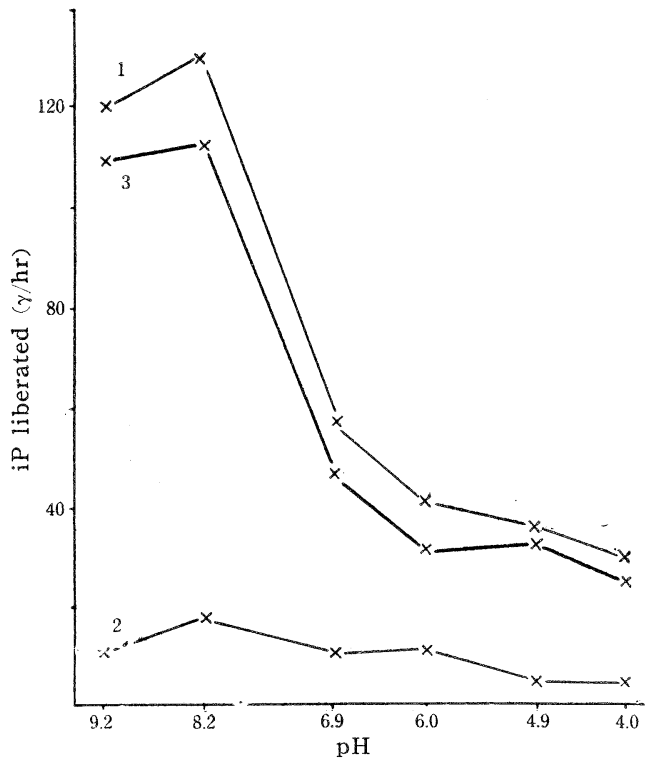

FIx. 5 Degradation of TDP by Dog Kidney Homogenate.

1. Total iP liberated.

2. iP liberated from endogenous substrate.

3. iP liberated from TDP by enzyme reaction. thawing as well as extraction with surface-active substances failed to show good results. When brains were cut into small pieces and autolyzed in water aseptically, the activity of the soluble part increased considerably. On the contrary, when brains were first homogenized and then autolyzed, the effect of autolysis was not observed.

At any rate, as the activity of rat brain enzyme was not so high, it was difficult to examine the nature of the enzyme more thoroughly.

\section{TDP-Decomposing Activity in Dog Kidneys}

\section{1. pH-Activity Curve of the Dog} Kidney Homogenates

With dog kidney homogenate, relatively strong activity was observed at $\mathrm{pH} 8$ to 9 , and differing from the case of rat brains, the secondary low peak was observed 
adjacent to $\mathrm{pH} 4.9$, as illustrated in Fig. 5.

2. pH-Activity Curve of the Soluble Enzyme Preparation from the Supernatant of Dog Kidney Homogenate

A fresh dog kidney weighing $52 \mathrm{~g}$ was cut into small pieces, $120 \mathrm{ml}$ of water was added, and organ was homogenized for one minute in a Waring blendor. The homogenate was centrifuged at 2,500 rpm for 15 minutes. The $\mathrm{pH}$ of the supernatant $(110 \mathrm{ml})$ was adjusted to 5.2 with diluted acetic acid and the solution was centrifuged at $2,000 \mathrm{rpm}$ for 15 minutes. The resulting supernatant $(80 \mathrm{ml})$ was clear and colored red brown. The proteins of the supernatant were precipitated by adding acetone (final concentration, $60 \mathrm{v} / \mathrm{v}$ per cent) at $0^{\circ}$ and centrifuged. The supernatant was decanted off, and the precipitate was dissolved in water and reprecipitated with saturated ammonium sulfate, followed by centrifugation. The precipitate was dissolved in small amount of one per cent $\mathrm{KCl}$ solution, and dialysed against water for 24 hours. A small amount of insoluble protein formed was centrifuged off, and the supernatant was used for the experiment. From Fig. 6, it is seen that the enzyme activity was not so high, and the maximum degradation of TDP occurred at an acidic region.

\section{3. pH-Activity Curve of Dog Kidney Autolysate}

Dog kidney autolysate was tentatively prepared according to the initial step

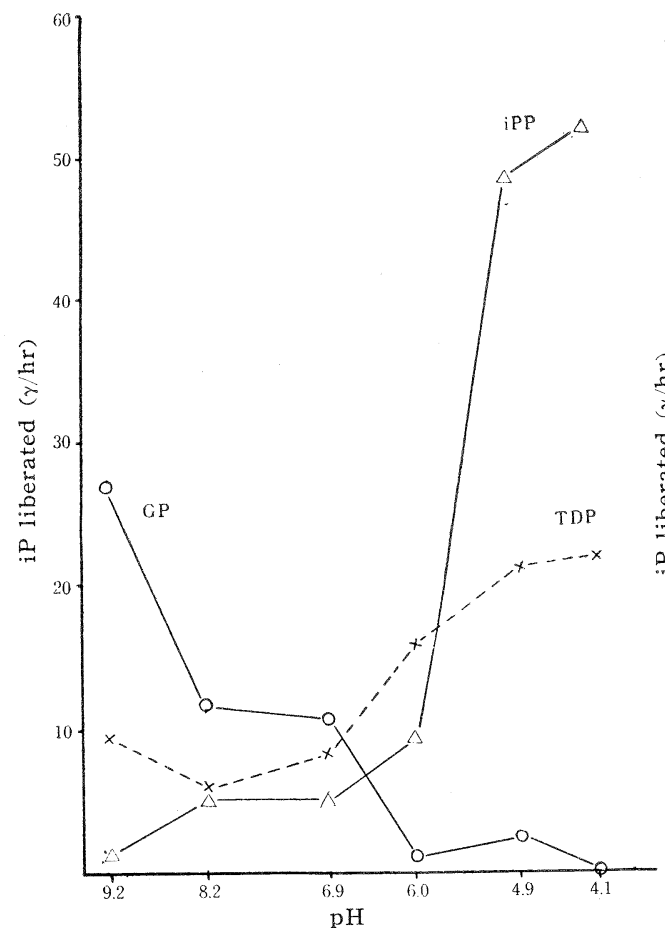

FIG. 6 Degradation of TDP by the Soluble Enzyme Preparation from the Supernatant of Dog Kidney Homogenate.

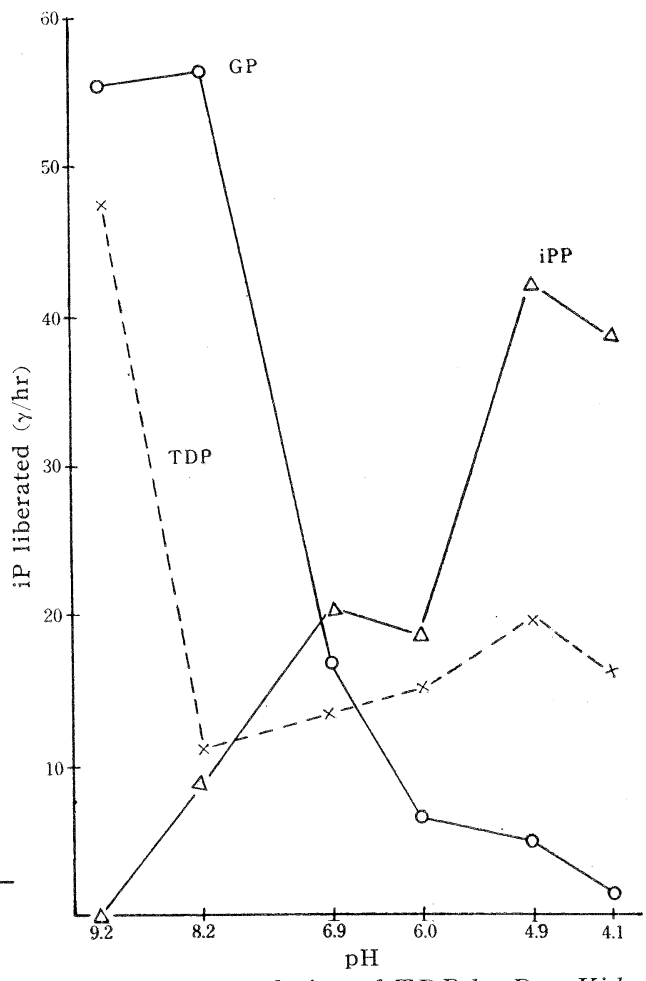

FIg. 7 Degradation of TDP by Dog Kidney Autolytic Extract. 
of the method of Abul-Fadl et al. (18) who used the procedure for purifying alkaline phosphatase. As this extract showed a relatively high activity at $\mathrm{pH}$ 9.2, its pH-activity relationship was examined. The method for the preparation was largely the same as that of bovine kidney extract described below. The pH-activity curve is illustrated in Fig. 7. In this case, the TDP-decomposing activity was stronger at an alkaline region, suggesting that the activity for decomposing TDP is not confined to a single enzyme. Under these conditions non-enzymatic iP liberation from TDP at $\mathrm{pH} 9.2$ was not observed. For examining the nature of these kinds of enzyme thoroughly, bovine kidney was used.

Studies on the TDP-decomposing Enzyme of Bovine Kidney

\section{1. pH-Activity Curve of Bovine Kidney Homogenate}

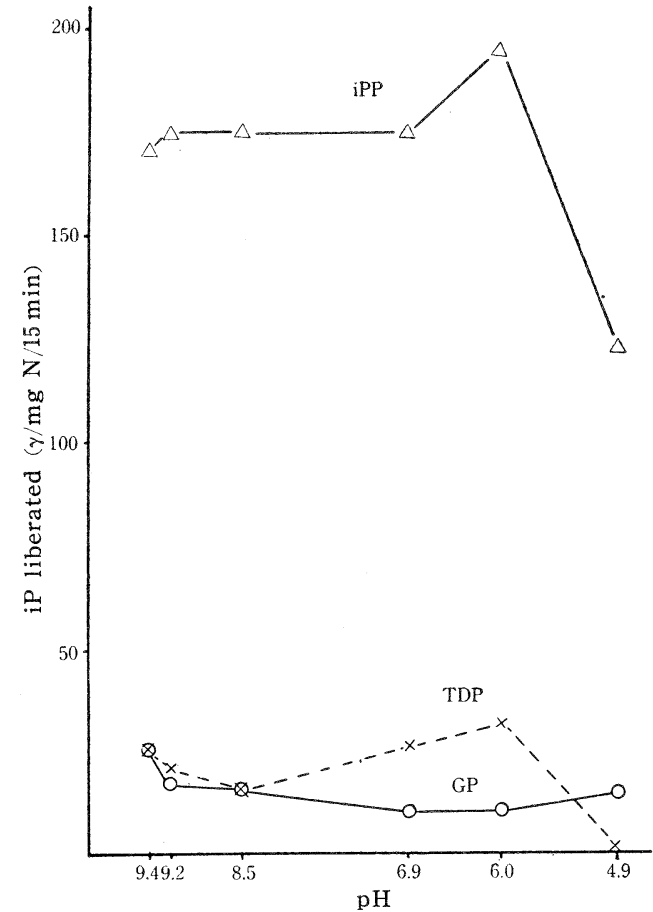

FIG. 8 Degradation of TDP, GP and $i P P$ by Bovine Kidney Homogenate.

As is illustrated in Fig. 8, extremely high iPPase activities were observed in bovine kidney homogenates. Relatively strong TDP decomposition was found at $\mathrm{pH} 9$ and 6 , whereas relatively strong GP decomposition at $\mathrm{pH} 9$ and 5 . In this experiment, bovine kidneys were obtained from a butchery as freshly as possible, but 2 to 3 hours elapsed after butchering.

\section{Preparation of the Crude Enzyme}

Largely based upon the method of Abul-Fadl et al. (18), crude enzyme was prepared as follows. $6,000 \mathrm{~g}$ of bovine kidneys were decapsulated, and the adipose tissue and pelvis were removed. All the cortex and the soft part of the medulla were collected, and minced well. $4050 \mathrm{~g}$ of the mince was obtained. $2535 \mathrm{ml}$ of water, $1015 \mathrm{ml}$ of acetone, $200 \mathrm{ml}$ each of toluene and ethyl acetate were added to the mince and mixed well. The whole was allowed to stand at room temperature $\left(20^{\circ}\right)$ for 3 days

with occasional stirring, followed by presseing throngh a cheese cloth, whereby a turbid fluid was obtained. By filtering through Toyo Filter paper No. 2, a faint yellow-colored clear extract was obtained $(3750 \mathrm{ml}) . \quad 2500 \mathrm{ml}$ of ice-cold pure acetone $\left(2 / 3\right.$ volumes of the extract) was added slowly at $0^{\circ}$, and the resulting precipitate was centrifuged down at $2500 \mathrm{rpm}$ for 30 minutes. The precipitate was transferred to a Buchner funnel with a small volume of cold pure acetone. The cake of the precipitate was washed twice with the same solvent and dried in a vacuum desiccator. Almost white protein powder (acetone-dried 
crude enzyme), was obtained, which showed relatively high TDPase and GPase activities at $\mathrm{pH} 9.2$.

\section{Denaturation, Inhibition and Activation}

Using the crude enzyme, the following experiments were performed to elucidate the outlines of the difference between TDPase and GPase.

Heat Treatment - The degree of the denaturation at pH 9.2 was examined by preincubation of the above enzyme at $50^{\circ}$ and $55^{\circ}$. The activities for both TDP and GP were determined at $\mathrm{pH}$ 9.2. TDPase activity was slightly more labile to heat treatment, but the decisive difference to permit the separation of the two enzymes was not observed. When preincubated at $\mathrm{pH} 5.0$, both TDPase and GPase were rapidly inactivated.

Inhibition by Metal Ions - - The activity of both TDPase and GPase was inhibited by metal ions. The activity was determined 10 minutes after adding an inhibitor. The inhibition of TDPase activity by $\mathrm{Cu}^{++}$or $\mathrm{Zn}^{++}$was slightly more pronounced than that of GPase, but withonr decisive difference (Table III).

TABLE III

Inhibition of TDPase and GPase of Bovine Kidney by $\mathrm{Cu}^{++}$and $\mathrm{Zn}^{++}$.

\begin{tabular}{|c|c|c|c|}
\hline \multirow{2}{*}{ Metal salt } & \multirow{2}{*}{ concentration } & \multicolumn{2}{|c|}{ Inhibition } \\
\hline & & TDPase & GPase \\
\hline & $M$ & per cent & per cent \\
\hline $\mathrm{CuSO}_{4}$ & $\begin{array}{l}0 \\
0.0005 \\
0.001 \\
0.002\end{array}$ & $\begin{array}{c}0 \\
35.4 \\
38.5 \\
63.7\end{array}$ & $\begin{array}{c}0 \\
1.7 \\
5.4 \\
25.5\end{array}$ \\
\hline $\mathrm{ZnSO}_{4}$ & $\begin{array}{l}0 \\
0.0005 \\
0.001 \\
0.002\end{array}$ & $\begin{array}{c}0 \\
43.5 \\
58.5 \\
62.7\end{array}$ & $\begin{array}{c}0 \\
30.4 \\
37.2 \\
43.7\end{array}$ \\
\hline
\end{tabular}

Activating Effect of Magnesium Ion and Inhibiting Effect of Fluoride The final concentration of $\mathrm{Mg}^{++}$used was 0.1 per cent as $\mathrm{MgSO}_{4}$, and that of fluoride $\mathrm{M} / 50$. This enzyme reaction was found to be apparently activated by

TABLE IV

Influence of Magnesium Salt and Fluoride on the TDPase and GPase of Bovine Kidney

\begin{tabular}{l|cc}
\multicolumn{1}{c|}{ Addition } & & Activity \\
& TDPase & GPase \\
\hline & per cent & per cent \\
Complete system & 100 & 100 \\
Without $\mathrm{Mg}^{++}$ & 77.7 & 84.1 \\
With $\mathrm{F}^{-}$ & 84.3 & 87.5 \\
With $\mathrm{Mg}^{++}+\mathrm{F}^{-}$ & 70.3 & 80.1
\end{tabular}


$\mathrm{Mg}^{++}$. However, the inhibitiory effect of fluoride was not so great, and it was influenced by the addition of $\mathrm{Mg}^{++}$(Table IV).

\section{Purification of the Enzyme}

Ammonium Sulfate Fractionation - Acetone-dried crude powder was dissolved in water, the insoluble protein was centrifuged off, and the clear supernatant was fractionated witlh ammonium sulfate. The results are illustrated in Table V. The enzyme activity was relatively polydisperse, being distributed in many fractions. Protein concentration and total activity in a fraction were highest at 0.6 to 0.8 saturation, and the activity ratio (TDPase/GPase) was also greatest at that fraction. However, as a whole, the variation of the ratio was not so remarkable.

TABLE V

Effect of Ammonium Sulfate Fractionation on Acetone-Dried Crude Enzymes of Bovine Kidney

Crude enzyme powder, $12 \mathrm{~g} \longrightarrow$ dissolved in $500 \mathrm{ml}$ of dist. water

$\longrightarrow$ centrifuged at $3,000 \mathrm{rpm}, 20 \mathrm{~min} \longrightarrow$ supernatant, $470 \mathrm{ml}$

$\longrightarrow$ fractionation $\longrightarrow$ dialysis

\begin{tabular}{|c|c|c|c|c|c|c|c|}
\hline \multirow{2}{*}{ Fraction } & \multirow{2}{*}{ Saturation } & \multirow{2}{*}{ Volume } & \multirow{2}{*}{$\begin{array}{c}\text { Total } \\
\text { protein }\end{array}$} & \multirow{2}{*}{ Protein } & \multicolumn{3}{|c|}{ Specific activity $(\gamma \mathrm{iP} / m g \mathrm{~N} / h r)$} \\
\hline & & & & & TDPase & GPase & $\begin{array}{c}\text { TDPase } \\
\text { GPase }\end{array}$ \\
\hline & & $m l$ & $m g$ & per cent & & & \\
\hline Homogenate & & - & - & 1.12 & 80.0 & 70.8 & 1.13 \\
\hline Crude extract & & 470 & 5781 & 1.23 & 204.8 & 214.0 & 0.95 \\
\hline I & $0-0.5$ & 62.5 & 969 & 1.55 & 192.8 & 184.8 & 1.04 \\
\hline II & $0.5-0.6$ & 17.5 & 273 & 1.60 & 169.2 & 165.2 & 1.02 \\
\hline III & $0.6-0.7$ & 62.5 & 1275 & 2.04 & 175.2 & 136.0 & 128 \\
\hline IV & $0.7-0.8$ & 50.0 & 456 & 0.91 & 391.2 & 304.0 & 1.29 \\
\hline V & $0.8-0.95$ & 15.0 & 39 & 0.26 & 1092 & 1180 & 0.92 \\
\hline VI & $0.95-1.0$ & 7.0 & 5 & 0.08 & 1052 & 2048 & 0.50 \\
\hline
\end{tabular}

Trypsin Treatment Fractions I, II, and III in ammonium sulfate fractionation (Table V) were combined (total volume, $124 \mathrm{ml}$; total protein, $2200 \mathrm{mg}$; ca. 1.8 per cent), and $125 \mathrm{mg}$ of crystalline trypsin supplied from the Mochida Chemical and Co. were added to the combined solution. $\mathrm{pH}$ was adjusted to 8 by adding sodium bicarbonate. After 3 hour incubation at $37^{\circ}$, kaolin was added to adsorb trypsin and the mixture was centrifuged. This adsorption was repeated twice. The supernatant was refractionated with ammonium sulfate. The results of the refractionation are given in Table VI. An increase in the specific activity of the enzymes was noticed, but the activity ratio TDPase' GPase, showed a considerable variation, and the separation of the two activities did not result.

Zone Electrophoresis - The following results were obtained from zone electrophoresis of the crude enzyme using a starch column. In Fig. 9, electrophoresis was carried out under conditions similar to that of the separation of serum proteins (veronal buffer, $\mathrm{pH}$ 8.6. $\mu=0.1$ ). The distribution of proteins was relatively complicated. The decomposing activities for both TDP and GP had an electrophoretic mobility similar to that of $\beta$-globulin, both activities show- 


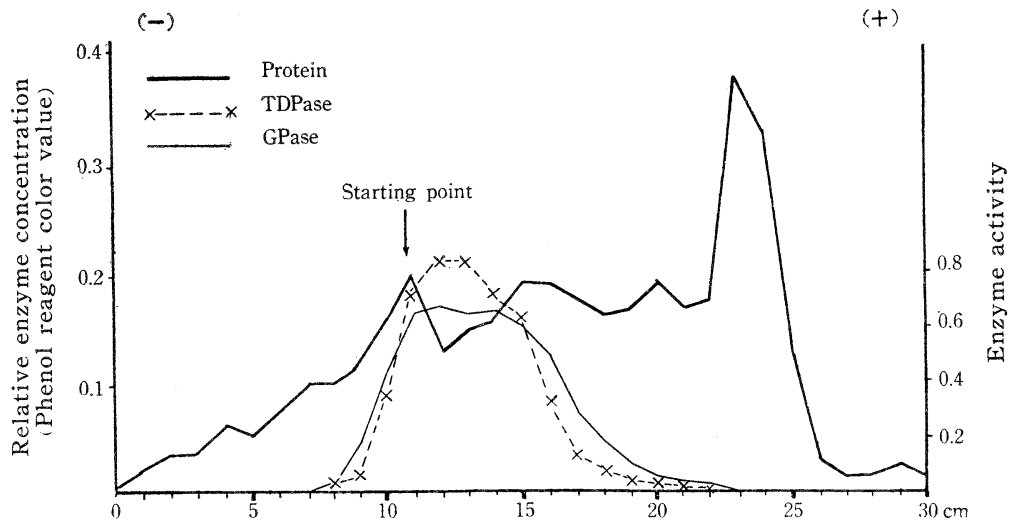

Fig. 9 Effect of Zone Electrophoresis on the Enzyme Activity of Bovine Kidney. Condition for zone electrophoresis: starch column, $1.5 \times 4.5 \times 30 \mathrm{~cm} ; 240 \mathrm{~V}$; $10 \mathrm{~mA} ; 9.5 \mathrm{hr}$; veronal buffer; $\mathrm{pH} 8.6 ; \mu=0.1$

TABLE VI

Effect of Trypsin Treatment and Refractionation with Ammonium Sulfate on the Enzyme Activity of Bovine Kidney

Fr. I, II, and III of Table V (total volume $124 \mathrm{ml}$, protein $2200 \mathrm{mg}$, ca. $1.8 \%)+$ crystalline trypsin $124 \mathrm{mg} \longrightarrow \mathrm{pH} 8.0,37^{\circ}, 3 \mathrm{hr} \longrightarrow$ removal of trypsin by kaolin adsorption (twice) $\longrightarrow$ fractionation $\longrightarrow$ dialysis

\begin{tabular}{|c|c|c|c|c|c|c|c|}
\hline Fraction & Saturation & Volume & $\begin{array}{c}\text { Total } \\
\text { protein }\end{array}$ & Protein & $\begin{array}{c}\text { Specific act } \\
\text { TDPase }\end{array}$ & $\begin{array}{l}\mathrm{P} / m g \mathrm{~N} / h r) \\
\text { GPase }\end{array}$ & $\begin{array}{c}\text { TDPase } \\
\text { GPase }\end{array}$ \\
\hline & & $m l$ & $m g$ & per cent & & & \\
\hline I & $0-0.5$ & 15 & 180 & 1.2 & 370 & 628 & 0.59 \\
\hline II & $0.5-0.6$ & 8 & 74 & 0.93 & 689 & 864 & 0.80 \\
\hline III & $0.6-0.7$ & 7 & 35 & 0.50 & 1700 & 1500 & 1.13 \\
\hline IV & $0.7-0.8$ & 5 & 38 & 0.75 & 1524 & 1148 & 1.33 \\
\hline V & $0.8-0.9$ & 8.5 & 12 & 0.24 & 2188 & 3480 & 0.64 \\
\hline $\mathrm{VI}$ & $0.9-1.0$ & 4 & 4.6 & 0.14 & 772 & 1692 & 0.46 \\
\hline
\end{tabular}

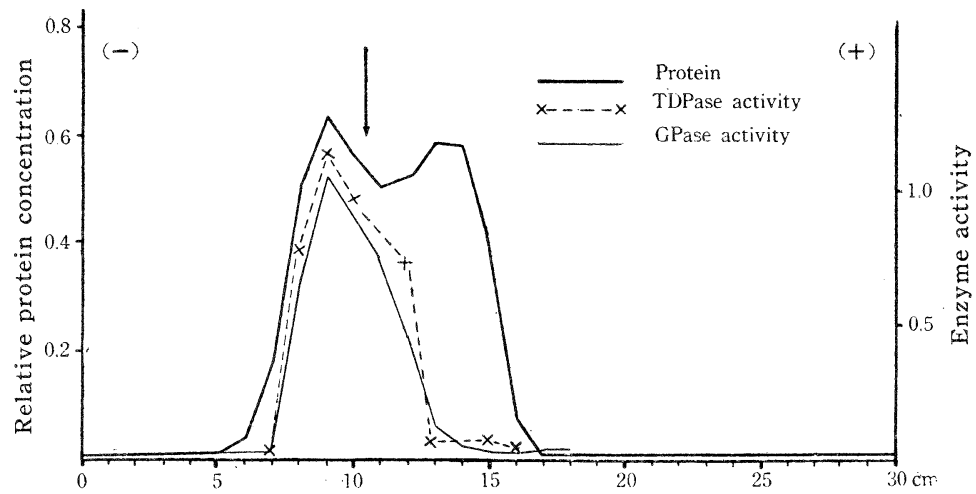

Fig. 10 Effect of Zone Electrophoresis on the Enzyme Activity of Bovine Kidney.

Conditions fer zone electrophoresis: starch column, $1.5 \times 3 \times 30 \mathrm{~cm} ; 160 \mathrm{~V}$; $10 \mathrm{~mA}$; $9 \mathrm{hr}$; veronal buffer; $\mathrm{pH} 7.5, M / 20$ 
ing a single peak, which was however considerably broad. Fig. 10 shows an electrophoretic diagram at $\mathrm{pH} 7.6$ (veronal buffer, $M / 20$ ). In this case, the velocity of migration decreased, and both TDPase and GPase migrated to the negative pole. Fig. 11 shows an electrophoretic diagram at $\mathrm{pH} 6.6$ (citrate buffer, $M / 20$ ). The sample was started from the middle of the starch column. The peak of the activities for both TDP and GP did not migrate to either side, but dispersed broadly. In any case the separation of TDPase and GPase was not effected.

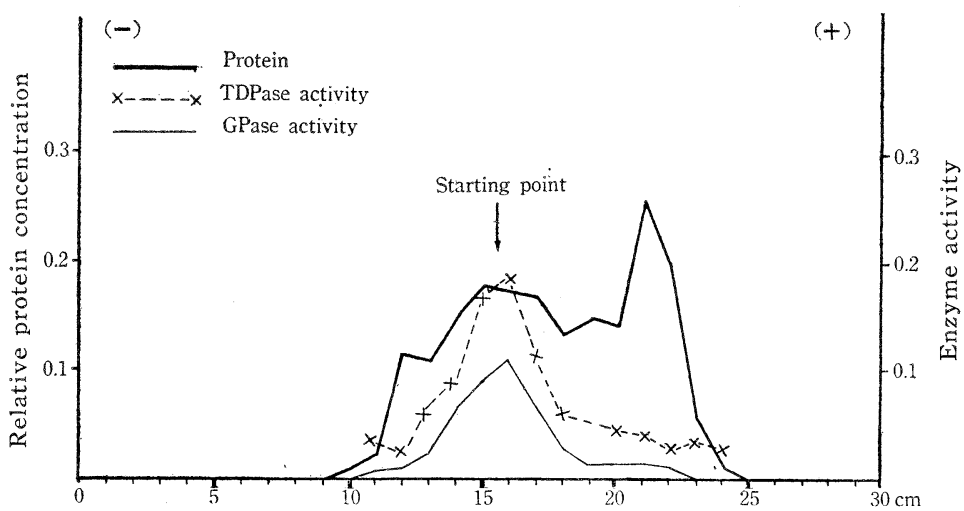

FIG. 11 Effect of Zone Electrophoresis on the Enzyme Activity of Bovine Kidney.

Conditions for zone electrophoresis: starch column, $1.5 \times 3 \times 30 \mathrm{~cm} ; 160 \mathrm{~V}$;

$15 \mathrm{~mA} ; 14 \mathrm{hr}$; citrate buffer, $\mathrm{pH} 6.6, M / 20$

The active part in the crude enzyme obtained by electrophoresis under the same conditions as in Fig. 9, i.e., a section of $5 \mathrm{~cm}$ from the starting line for the positive pole was cut out, and the proteins extracted from this section were refractionated with ammonium sulfate. The results of the refractionation is

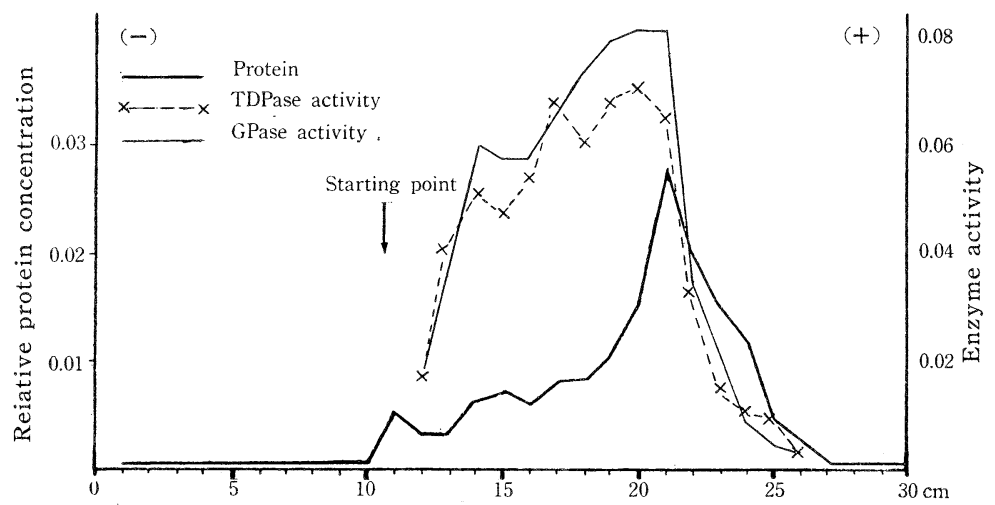

Fig. 12 Zone Electrophoresis of the Ammonium Sulfate Frac-tions Obtained from Zone Electrophoresis

Conditions for zone electrophoresis: starch column, $1.5 \times 3 \times 30 \mathrm{~cm} ; 300-240 \mathrm{~V}$; $10 \mathrm{~mA} ; 30 \mathrm{hr}$; veronal buffer; $\mathrm{pH} 8.6, \mu=0.1$ 
shown in Table VII. The activity ratios, TDPase/GPase, were relatively constant, but fractions with high specific activities were easily obtained. The specific activity was especially high at more than 0.6 saturation. However, a considerable activity was also observed with the fraction of less than 0.5 saturation. Fractions II to IV in Table VII were combined and the second electrophoresis was carried out. The result is illustrated in Fig. 12. From this figure, it is noticeable that the enzyme was partially purified, but the separation of the decomposing activities for TDP and GP was not observed.

TABLE VII

Ammonium Sulfate Fractionation of an Active Extract Obtained by Zone Electrophoresis.

\begin{tabular}{|c|c|c|c|c|}
\hline \multirow{2}{*}{ Fraction } & \multirow{2}{*}{ Saturation } & \multicolumn{3}{|c|}{ Specific activity $(\gamma \mathrm{iP} / m g \mathrm{~N} / h r)$} \\
\hline & & GPase & TDPase & TDPase/GPase \\
\hline Crude extract & & 1050 & 1353 & 1.29 \\
\hline I & $0-0.5$ & 543 & 702 & 1.29 \\
\hline II & $0.5-0.6$ & 1098 & 1548 & 1.41 \\
\hline III & $0.6-0.7$ & 2463 & 3045 & 1.24 \\
\hline IV & $0.7-0.8$ & 2517 & 3054 & 1.21 \\
\hline $\mathrm{V}$ & $0.8-0.9$ & 2517 & 2886 & 1.15 \\
\hline VI & $0.9-1.0$ & 2355 & 3000 & 1.27 \\
\hline
\end{tabular}

Ion Exchange Chromatography Using Amberite XE-64, the crude enzyme solution was chromatographed. The resin was bufferized to a slightly acidic $\mathrm{pH}$ with citrate buffer. The adsorbed proteins were eluted with sodium borate (pH 9.2). When the resin was bufferized to $\mathrm{pH} 5.4$, the enzyme activity was not adsorbed (Fig. $13 a$ ). After bufferizing the resin to $\mathrm{pH} 5.15$, the enzyme activity was completely adsorbed (Fig. $13 b$ ). In the case of bufferizing the resin to the intermediate $\mathrm{pH}$ of 5.3 , the enzyme activity appeared in both the non-adsorbed and adsorbed fractions (Fig. $13 c$ ). However, in any case, the separation of TDPase and GPase was not effected.

Discussion on the Purification of the Enzyme Protein - As to whether the TDPase and the GPase are the same enzyme protein or not, several efforts were performed besides these experiments. When the enzyme solution was chromatographed with a special technique, results suggesting a partial separation of TDPase and GPase were obtained. With this technique, however, the denaturation of the enzyme protein was so pronounced that decisive data could not be obtained. On the other hand, enzyme peparations showing the higher TDPase/ GPase ratio of 2 to 2.5 were obtained with repeated fractionations with acetone. However, in spite of many efforts, much higher ratio could not be obtained. At any rate, it was presumed that the TDPase and the GPase would be of a very similar nature.

5. $p H$-Activity Curve and Substrate Specificity of the Partially Purified Enzyme pH-Activity Curve … Fig. 14 shows the pH-activity curve of the enzyme preparation treated with trypsin. Strong GPase, TDPase, and TMPase activities were observed at pH 9. However, it was remarkable that iPPase active in 

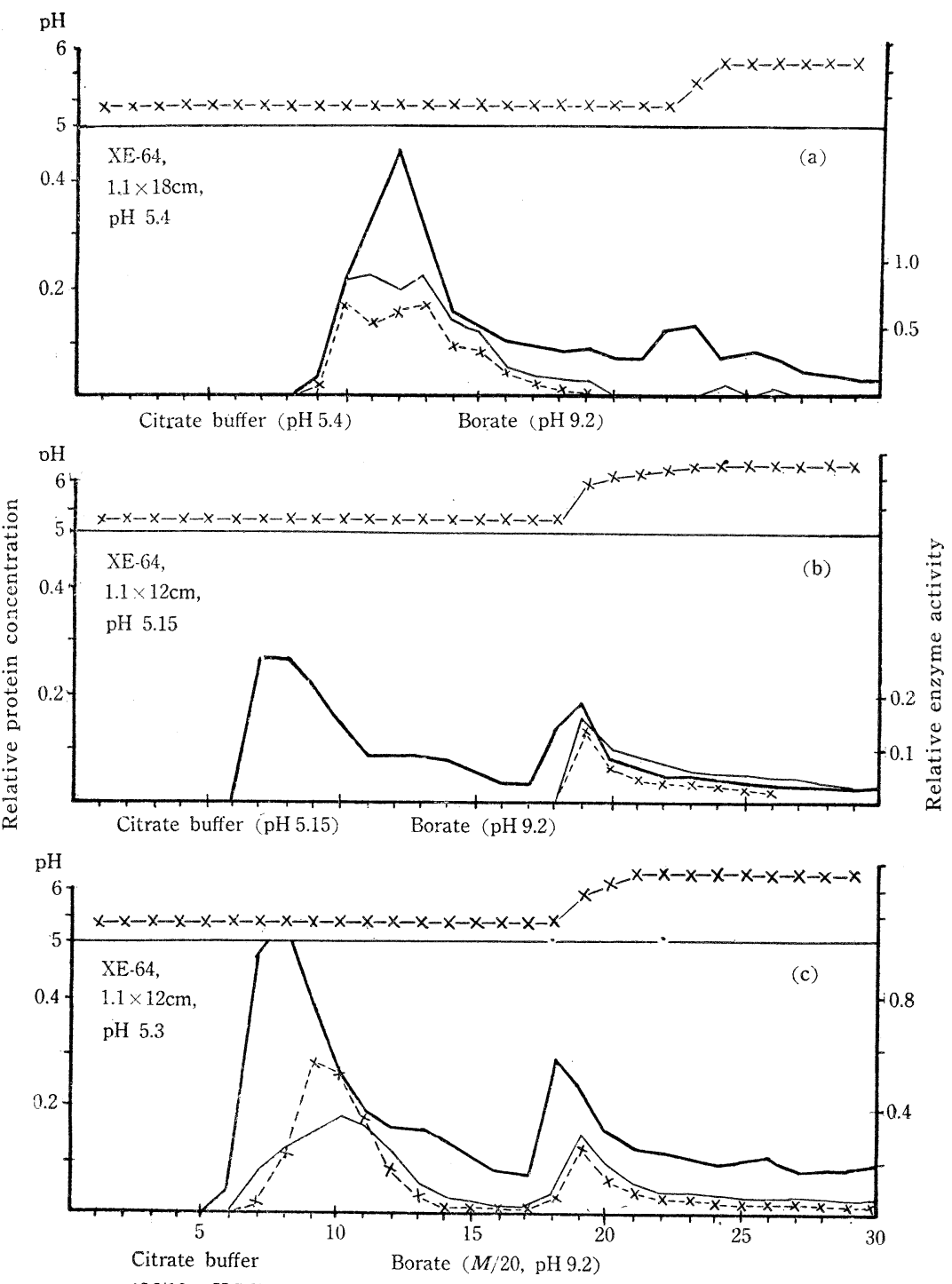

$(M / 10, \mathrm{pH} 5.3)$

Effluent (mi)

Fig. 13 Effect of Ion Exchange Chromatography on the Crude Enzyme of Bovine Kidney.

Column: Amberite XE-64, approx. $25 \mathrm{mg}$ crude enzyme chromatographed.

- Protein, GPase, …... TDPase

alkaline region was scarcely detected. Preparations purified further by acetone fractionation showed no iPPase activity at $\mathrm{pH} 9$.

Substrate Specificity - Although the separation of activities for TDP and GP was not accomplished, the substrate specificity was once examined with the 


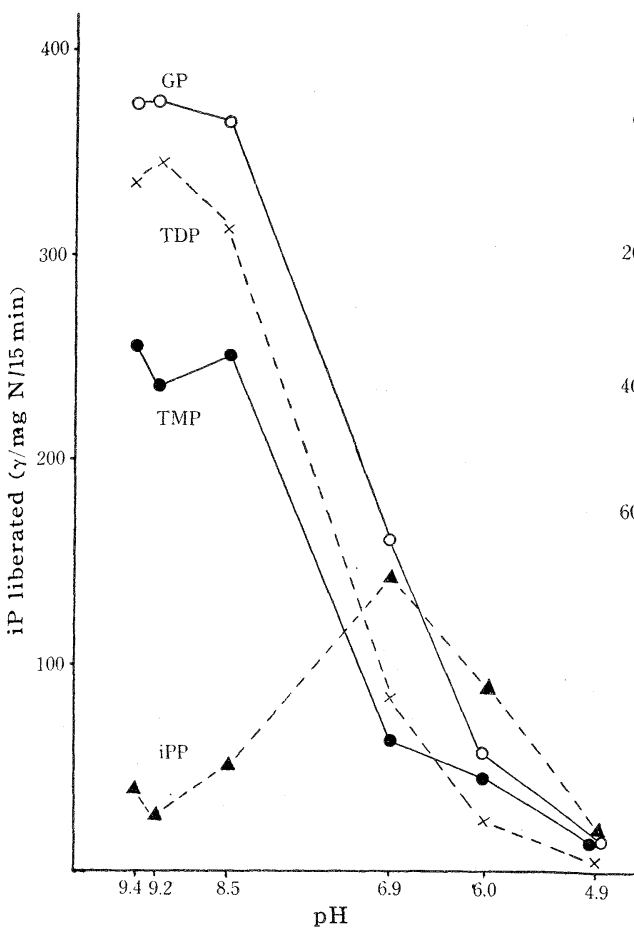

FIg. 14 pH-Activity Curve of Partially Purified Bovine Kidney Phosphatase for Various Substrates.
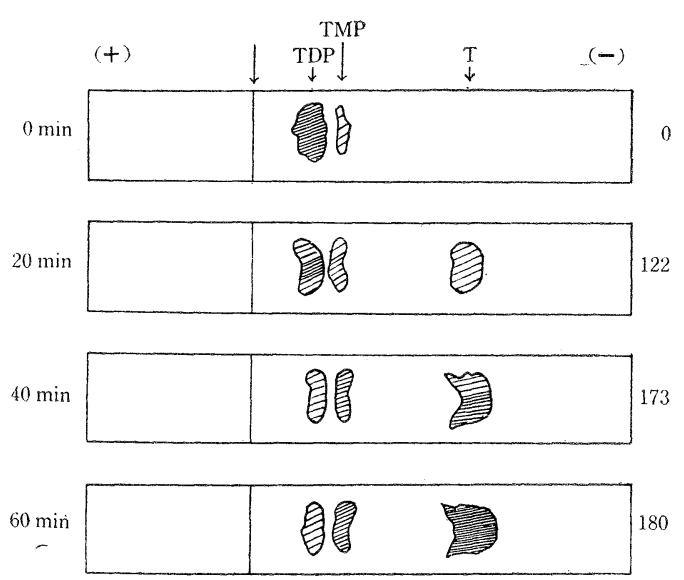

Fig. 15 Analysis of Reaction Products by Paper Electrophoresis

Enzyme : partially purified kidney phospatase Electrophoresis : Toyo Filter Paper No. 50, $2 \times 25 \mathrm{~cm}, 1.35 \mathrm{~mA} / \mathrm{cm}, 1300 \rightarrow 500 \mathrm{~V}, 3 \mathrm{hr}$, $M / 60$ acetate buffer, $\mathrm{pH} 5.4$

Detection : Thiochrome Reaction

iP determination: Gomori's method

The figures on the right, $\gamma \mathrm{P}$ per $2 \mathrm{ml}$ reaction mixture.

enzyme prepared as pure as possible. As shown previously, TMP was de composed by this enzyme. The libe-

rated $\mathrm{iP}$ in $\gamma$ per $2 \mathrm{ml}$ of the reaction mixture during 15 minutes at $\mathrm{pH} 9.2$ was 63.7, 55.0, 74.1, and 62.1 for ATP, adenosine-5'-phosphate (A5' P), TDP, and GP, respectively, in equimolar cnncentration. Thus $\mathrm{ATP}$ and $\mathrm{A} 5^{\prime} \mathrm{P}$ were also decomposed by this enzyme preparation.

6. Experiments on the Mechanism of the TDP-Decomposibg Reaction

Production of iP Rather than iPP by the Decomposition of TDP - As iPPase activity capable of acting at $\mathrm{pH} 9.2$ was scarcely contained in this enzyme preparation, iPP must accumulate if iPP is produced by splitting TDP. However, iPP accumulation was not detected, when determined by Kornberg's method (6), but iP was found to be liberated from TDP. Thus the reaction

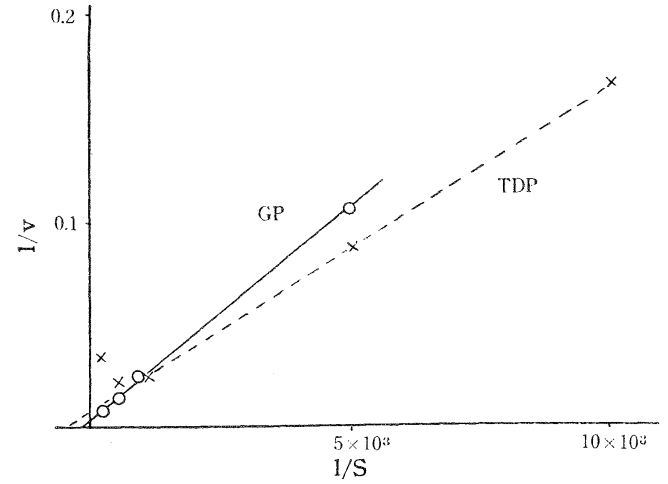

Fig. 16 Lineweaver-Burk Plot for the Action of Bovine Kidney Enzyme on TDP and $G D$. 


$$
\mathrm{TDP} \longrightarrow \mathrm{T}+\mathrm{iPP}, \quad \mathrm{iPP} \longrightarrow 2 \mathrm{iP}
$$

are excluded to be the actual process.

Analysis of the Reaction Products by Paper Electrophoresis In Fig. 15, the production of iP and the rise and fall of TDP, TMP, and thiamine are shown following the time course of the reaction. In the Figure, the intensity of the thiochrome reaction is exressed by the density of oblique lines.

As stated above, TDP samples used contained a trace of TMP as a contaminant. As relatively high TMPase activity was present in the enzyme preparation, the spot of the contaminated TMP will disappear in a short time if TMP was not produced from TDP. In this experiment, however, the spot of TMP did not disappear but showed a tendency to increase in intensity as the reaction proceeded. This is to be interpreted that TMP is produced from TDP. Thus it is assumed that the degradation reactions expressed as

$$
\mathrm{TDP} \longrightarrow \mathrm{TMP}+\mathrm{iP}, \quad \mathrm{TMP} \longrightarrow \mathrm{T}+\mathrm{iP}
$$

must be the actual case.

\section{Kinetic Analysis}

Substrate Concentration-Reaction Velocity Curve - As illustrated in Fig. 16, the velocity of the decomposing reaction reached a maximum at the substrate concentration of about $10^{-3} M$. It is very interesting that the reaction velocity decreased at higher substrate concentrations. Such inhibition by high substrate concentration was also noticed with TMP, but not in the case with GP.

According to the method of Lineweaver and Burk (19), reciprocals of the reaction velocity and the substrate concentration were plotted. The linear part of the plots (excluding the inhibited part) were extrapolated and the apparent Michaelis constants were calculated. Thus the values of $2 \times 10^{-3}$ and $5 \times 10^{-3} \mathrm{M}$ were obtained for TDPase and GPase, respectively.

Analysis of the Enzymes with the Competition between Substrates-As reported by Blaschko et al. (20), if two kinds of substrate $(A$ and $B$ ) are either decomposed by appropriative respective enzymes or exert no influence on each other ${ }^{2}$, there would be the following relation.

$$
v_{\mathrm{A}+\mathrm{B}}^{\max }=v_{\mathrm{A}}^{\max }+v_{\mathrm{B}}^{\max }
$$

where $v_{\mathrm{A}}$ represents the reaction velocity for substrate $A, v_{\mathrm{B}}$ that for substrate $B, v_{\mathrm{A}+\mathrm{B}}$ that in the presence of $A$ and $B$,

and $v^{\max }$ the maximum velocity.

On the contrary, if two kinds of substrate are decomposed by a single enzyme, there would be the following relation.

$$
v_{\mathrm{A}+\mathrm{B}}<v_{\mathrm{A}}+v_{\mathrm{B}}
$$

The higherthe concentration of substrate, the greater the difference. Finally, $v_{\mathrm{A}+\mathrm{B}}$ approaches to the maximum reaction velocity of the substrate whose $\mathrm{Mi}$ chaelis constant is smaller than the other. In another words, the velocity for the mixed substrates approaches to that of the substrate which combines with the enzyme more tightly.

Applying this theoretical ground, experiments were performed to analyze the enzyme preparation. Fig. 17 illustrates the results concerning TMP and

\footnotetext{
2 In many cases, this supposition is satisfied only approximately.
} 
GP. As the substrate concentration increased, $v_{\mathrm{TMP}+\mathrm{GP}}$ approached to $v_{\mathrm{TMP}}$. Fig. 18 illustrates the results concerning TDP and GP. Also in this case, as the substrate concentration increased, $v_{\mathrm{TDP}+\mathrm{GP}}$ approached to $v_{\mathrm{TDF}}$. Fig. 19 shows the results concerning TDP and TMP. $\quad v_{\text {TMP }+ \text { TDP }}$ reached a maximum at a concentration of about $\mathrm{M}$ / 1000 each and, when the concentration was increased further, $v_{\text {TDP }}+$ TMF become smaller than either $v_{\text {TDP }}$ or $v_{\text {TMF }}$.

From these results, next assumption will be drawn provided that the substrate inhibition is tentatively not brought into consideration. That is, in a reaction system expressed as

$$
\begin{aligned}
& \mathrm{TDP} E_{1} \longrightarrow \mathrm{TMP}+\mathrm{iP} \\
& \mathrm{TMP} E_{2} \longrightarrow \mathrm{T}+\mathrm{iP} \\
& \mathrm{GP}-E_{3} \longrightarrow \mathrm{G}+\mathrm{iP}
\end{aligned}
$$

the enzymes $E_{1}, E_{2}$, and $E_{3}$ are equal. It means that a single enzyme (socalled kidney alkaline phosphatase)

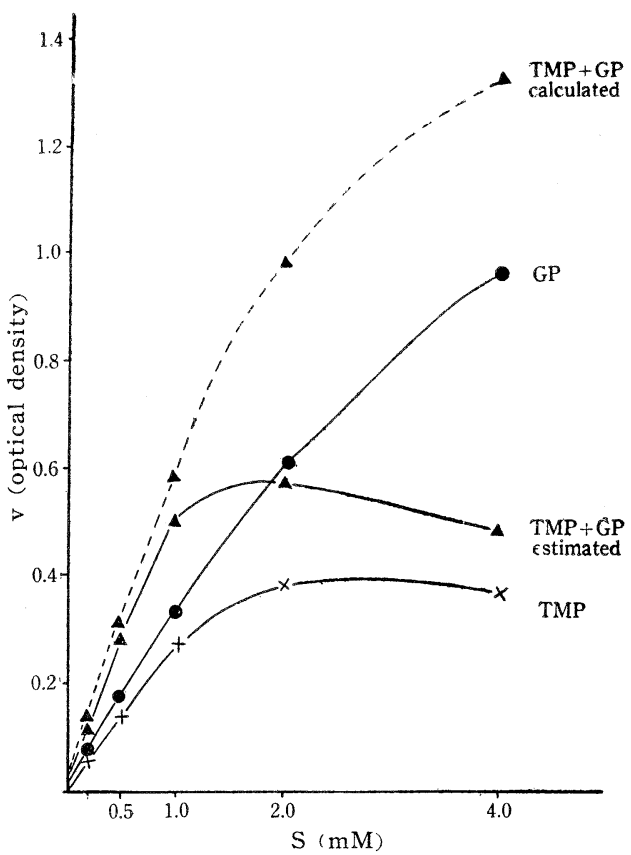

FIG. 17 Competition of Bovine Kidney Enzyme between TMP and GP acted upon TDP and liberated the phosphoric acid one by one.

However, decisive conclusion should be withholded until the nature of the inhibition caused by increasing the substrate concentration is clarified.

No inhibition being observed with GP, it is apparent that the inhibition mentioned above is not an inhibitiotn caused by iP produced.

Inability of Thiamine to Inhibit the Reaction - No inhibition was observed by the addition of thiamine up to about the equal concentration to the substrates (Table VIII).

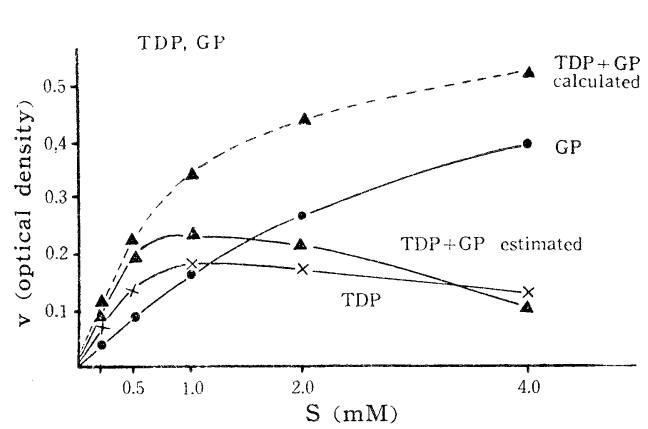

Fig. 18 Competition of Bovine Kidney Enzyme between TDP and GP

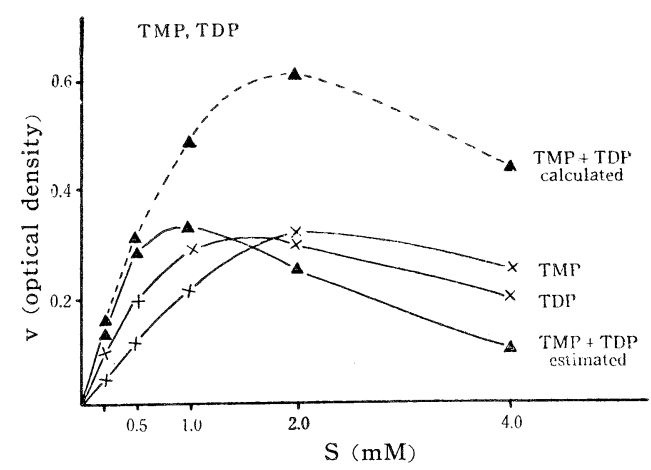

FIG. 19 Competition of Bovine Kidney Enzyme between TMP and TDP 
TABLE VIII

Invalidity of Thiamine to Inhibit Kidney Enzyme

\begin{tabular}{|c|c|c|c|}
\hline \multirow{2}{*}{$\begin{array}{l}\text { Subatrate } \\
(M / 1700)\end{array}$} & \multicolumn{3}{|c|}{ iP liberated $(\gamma / 15$ min $)$} \\
\hline & $\begin{array}{l}\text { Without } \\
\text { thiamine }\end{array}$ & $\begin{array}{l}\text { With thiamine } \\
\text { (final } M / 5,000 \text { ) }\end{array}$ & $\begin{array}{l}\text { With thiamine } \\
\text { (final } M / 1,000 \text { ) }\end{array}$ \\
\hline TDP & 22.9 & 22.3 & 22.4 \\
\hline TMP & 13.8 & 14.3 & 13.8 \\
\hline GP & 13.1 & 13.1 & 12.7 \\
\hline
\end{tabular}

\section{TDP-Decomposing Enzyme in Yeast Autolysate}

\section{Preparation of the Extract}

Packed dry bakers' yeast ${ }^{3}$ supplied from the Oriental Yeast and Co. ${ }^{4}$, was suspended in $M / 2$ phosphate buffer ( $\mathrm{pH} 7.2$ ), autolyzed at $38^{\circ}$ for 2.5 hours, and centrifuged. To the supernatant, solid ammonium sulfate was added to saturation, and the resulting precipitate was separated by centrifuging at 10,000 rpm for 60 minutes. The precipitate was dissolved in a small volume of water, dialyzed against running tap water for 24 hours, and was used for experiments.

\section{2. $p H$-Activity Curve}

Conditions employed for the determination of the activities were almost the same as described above except that citrate buffer was used. Fig. 20 illustrates

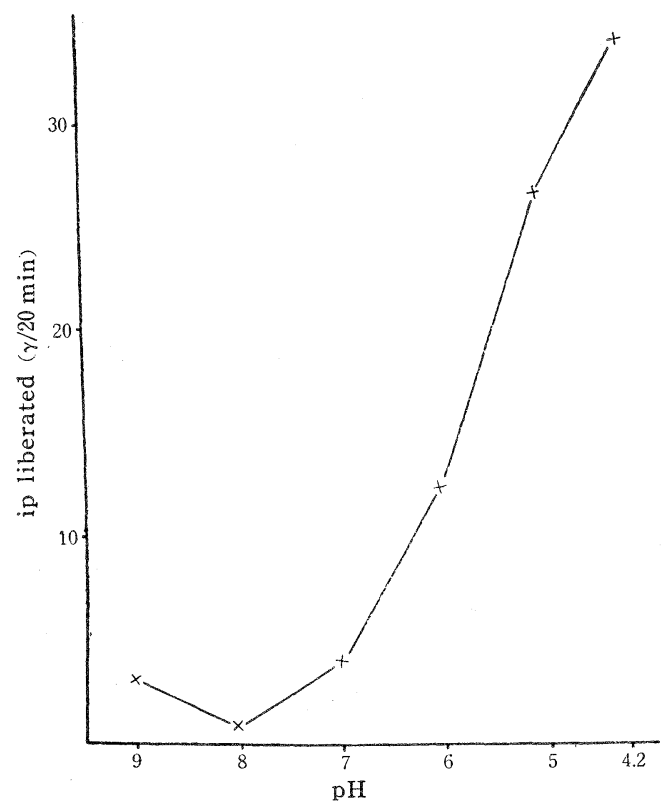

FIg. 20 pH-Activity Curve of TDP-Decomposing Enzyme of Yeast.

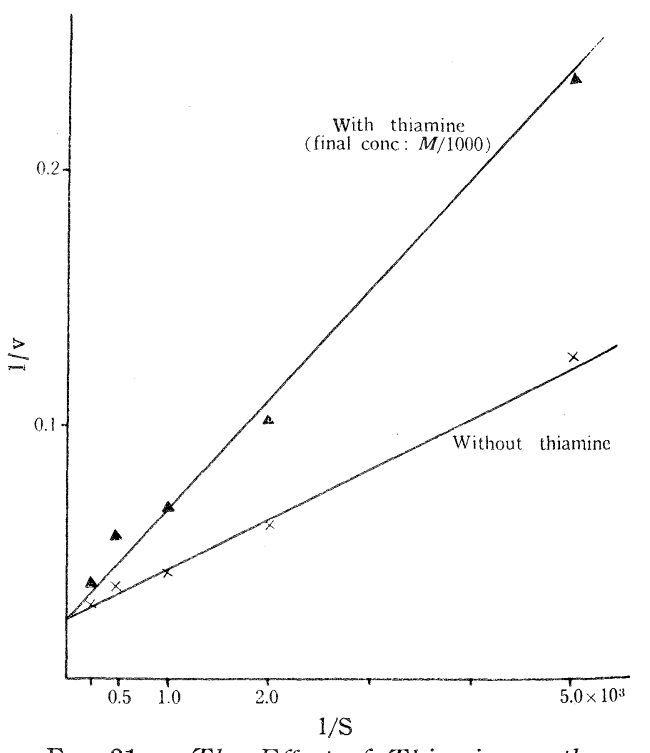

FIx. 21 The Effect of Thiamine on the Substrate Concentration-Reaction Velocity Curve of TDP-Decomposing Enzyme of Yeast $(p H 5.2)$

\footnotetext{
${ }^{3}$ Air dried yeast, made from a heat-stable strain. ${ }^{4}$ Chūō-ku, Tokyo
} 
the $\mathrm{pH}$-activity curve for TDP-decomposing activity showing the strong decomposition in acidic regions.

\section{Kinetic Analysis}

The substrate concentration-reaction velocity curve at $\mathrm{pH} 5.2$ showed that thiamine apparently inhibited the decomposition of TDP by this enzyme. Substrate inhibition was, under the conditions tested, not observed. It is worthy of note that the yeast enzyme is different from the bovine enzyme in these respects. Fig. 21 shows the Lineweaver-Burk plot, from which thiamine is assumed to inhibit the decomppsition of TDP competitively. Further detailed studies are necessary for clarifying the decomposition of TDP by yeast phosphatase.

\section{Inability of Inosine Diphosphatase to Degrade TDP}

The acetone powder of bovine liver mitochondria was perpared following the method of Plaut (7), and the cold water extract of the acetone powder was used. The reaction mixture contained $1.0 \mathrm{ml}$ of $M / 10$ tris buffer, $0.4 \mathrm{ml}$ of $M / 250$ substrate, $0.4 \mathrm{ml}$ of 1 per cent $\mathrm{MgSO}_{4}$ and $0.2 \mathrm{ml}$ of the enzyme. After 20 minute incubation at $37^{\circ}$, the liberated inorganic phosphate was estimated. When inosine diphosphate (IDP) was used as substrate, the liberated iP was 15 $\gamma$, whereas TDP and TMP failed to liberate iP. In this case, non-enzymatic decomposition of IDP during the colorimetric estimation was not observed. Thus this enzyme is shown to decompose IDP, but not TDP and TMP.

\section{SUMMARY}

Thiamine diphosphate-decomposing activities in the homogenates of rat brain, dog kidney' and bovine kidney were studied. Those in the autolysate of dog kidney, bovine kidney and yeast were fractionated, some of which were partially purified, and the enzymological properties were also studied with the following results.

1. When the liberation of inorganic phosphate was measured for determining thiamine diphosphate-decomposing activities, a turbidity caused by the reaction between thiamine and phosphomolybdate appeared. However, under suitable conditions, and in a settled concentration range, the extinction could be used as an indicator of degradation. Furthermore, the method of using ammonium chloride to extinguish the turbidity was retested and proved to be excellent and useful. It was applied to the present experiments.

2. $\beta$-Glycerophosphate-dephosphorylating activity in rat brain homogenates showed, under conditions used, two maxima at $\mathrm{pH} 9$ and 5. On the contrary, thiamine diphosphate-decomposing activity showed the highest value at approximately $\mathrm{pH} 9$, and, in addition, an accessary peak between $\mathrm{pH} 6$ and 7 . The degree of the inhibition for thiamine diphospate-decomposing activity by fluoride was much less than that for $\beta$-glycerophosphate-dephosphorylating activity, especially at $\mathrm{pH}$ 6.9. The activity for thiamine diphosphate was influenced to some extent by the change in osmotic pressure. The enzyme was presumed to exist in both soluble and insoluble fractions. 
3. Thiamine diphosphate-degrading activity in dog kidney homogenates showed a maximum between $\mathrm{pH} 8$ and 9 , but the activity was also observed below $\mathrm{pH}$ 6. The accessory activity peak was observed adjacent to $\mathrm{pH} 4.9$.

An enzyme preparation was obtained from the supernatant of the kidney homogenate by fractionating at various pH's. It decomposed thiamine diphosphate at acidic pH range, but its activity was not so high. Another enzyme preparation was obtained from the extract prepared by autolyzing kidneys in the mixed solvent containing water, acetone, toluene and ethyl acetate. This preparation degraded thiamine diphosphate more markedly at $\mathrm{pH} 9.2$.

4. Bovine kidney homogenates showed strong decomposing activities for inorganic pyrophosphate over a wide $\mathrm{pH}$ range. Besides these, they showed relatively high decomposing activities for thiamine diphosphate at $\mathrm{pH} 9$ and 6 , and also for $\beta$-glycerophosphate at $\mathrm{pH} 9$ and 5 (so-called alkaline and acid phosphatases).

5. Using the autolysate of bovine kidneys as the starting material, attempts for purification of the enzyme were made. In the partially purified enzyme preparations, no inorganic pyrophosphatase activity at $\mathrm{pH} 9.2$ was found. However, decomposing activities for both thiamine diphosphate and $\beta$-glycerophosphate were found, and it was difficult to separate them. These two activities showed the same behaviour when tested with ordinary zone electrophoresis and column chromatography. With ammonium sulfate fractionation, trypsin treatment, and acetone fractionation, especially with repeated acetone fractionations, the activity ratio (TDPase/GPase) somewhat shifted to the larger. But it was not clarified whether ther could be separated or not. It was presumed that the thiamine diphosphate-decomposing enzyme and the $\beta$-glycerophosphate-decomposing enzyme would be of a very similar nature.

6. Thiamine diphosphate-decomposing enzyme preparations obtained from bovine kidneys could also decompose ATP, adenosine-5'-phosphate, thiamine monophosphate, and $\beta$-glycerophosphate.

Presumptive mechanism for degradation is as follows.

$$
\mathrm{TDP} \longrightarrow \mathrm{TMP}+\mathrm{iP}, \quad \mathrm{TMP} \longrightarrow \mathrm{T}+\mathrm{iP}
$$

The activities for both thiamine diphosphate and thiamine monophosphate was inhibited by the increase in substrate concentration, but that for $\beta$-glycerophosphate was not. Thiamine showed no inhibitory action for these enzyme reactions. If the inhibition due to increase in substrate concentration is tentatively not brought into consideration, it is possible to assume from the kinetic analysis that the reactions mentioned above are catalyzed by a single enzyme.

7. Thiamine diphosphate-decomposing activity in the enzyme preparation obtained from yeast extracts showed strong action at acidic pH. With this enzyme, substrate inhibition was not observed. It was reinvestigated and confirmed that thiamine inhibits the decomposion of thiamine diphosphate by yeast enzyme. Furthermore, results were obtained indicating this inhibition to be of a competitive nature.

8. Thiamine diphosphate was not degraded by inosine diphosphatase. 


\section{ACKNOWLEDGEMENT}

The author is deeply indebted to Prof. Norio Shimazono for his kind advice and encouragement, and also to Dr. Taizo Matsukawa for the kind gift of synthetic cocarboxylase.

\section{REFERENCE}

1. Lohmann, K., and Schuster, P., Biochem. Z. 294, 188 (1937).

2. Ochoa, S., and Peters, R. A., Biochem. J. 32, 1501 (1938).

3. Westenbrink, H. G. K., VanDorp, D. A., Gruber, M. and Veldman, H., Enzymologia 9, 73 (1940).

4. Horie, S., J. Vitaminol. 3, 1 (1957).

5. Aoshima, Y., The 30th General Meeting of Japanese Biochemical Society, July, 1957.

6. Naidoo, O., and Pratt, O. E., Neurol. Neurosurg. Psychiat. 15, 164 (1952), Biochem. Biophys. Acta 16, 75 (1955).

7. Kornberg, A., and Pricer, W. C., J. Biol. Chem. 182, 763 (1950).

8. Plaut, G. W. E., ibid. 217, 235 (1955).

9. Miura, U., Fujiwara, M., Matsui, K., and Honda, M., Vitamins 7, 989 (1954).

10. Gomori, G., J. Lab. Clin. Med., 27, 955 (1942).

11. Uehara, K., private communication.

12. Yamamura, Y., Hayashi, T., and Watanabe, M., Vitamins 7, 596 (1954).

13. Fujita, A., and Hamamoto, E., ibid. 7, 989 (1954).

14. Folin, O., and Ciocalteu, V., J. Biol. Chem. 73, 628 (1928).

15. Lowry, O. H., Rosenbrough, N. J., Farr, A. L., and Randall, R. J., ibid. 193, 265 (1951).

16. Kornberg, A., ibid. 182, 782 (1950).

17. Potter, V. R., and Recknagel, R. O., Phosphorus Metabolism, 1, 383 (1951).

18. Abul-Fadl, M. A. M., King, E. J., Roche, J., and Thoai, N. van, Biochem. J. 44, 428 (1948).

19. Lineweaver, H., and Burk, D., J. Am. Chem. Soc., 56, 658 (1934).

20. Blaschko, H., Richter, D., and Schlossmann, H., Biochem. J., 31, 2187 (1937).

21. Shimazono, N., and Horie, S., Vitamins 12, 357 (1957).

22. Horie, S., J. Jap. Biochem. Soc. (Japanese) 28, 828 (1957). 